\section{観 察 記 録}

1） 1972 年 8 月 8 日〜10 日, スダジイ(コジイ)が 優占する照葉樹林内, およびそれに隣接した, シイの若 龄木にイヌッグやオオバヤシャブシ，クロモジなどが多 く混じった林で, 同時に最高 9 羽を観察した。確認方法 は、チュルチュルチュルと聞こえる専り, ヒーッ, ヒー ッと聞こえる鳴き声，および最短距離 $1.5 \mathrm{~m}$ からの目 慗による。

2) 同年 9 月 17 日, 同所にて幸丸政明氏が $2 \sim 3$ 羽 の轉りを記録。

3） 1973 年 4 月 10 日, 作業所内を流れる小川沿いの, 照葉樹林と落葉樹林が接するところで㗚っている 1 羽を 観察。翌 11 日には, アブラギリの造林地とスギの造林 地の境で 1 羽, クスの造林地で 2 羽, それに隣接した竹 林にて1羽，それぞれ賕り・鳴き声・目揧のすべてで確 認。

4) 同年 4 月 24 日，クスの造林地で囀る 1 羽を確認。 翌 25 日にはおらず。

確認方法が採集によらない観察だけのものであるた め, 確実性を欠く面もあるが, 次に述べるいくつかの点 から、これらの記録がイイジマムシクイのものであるこ とに間違いがないものと確信する。第 1 に, この種の溥 りには近縁のセンダイムシクイやメボソムシクイに似た 面があり，節まわしがそれらにそっくりなところむある （樋口，1971）が，前記したチュルチュルチュルと聞こ える䑧りは，明らかにそれら 2 種と区別できること。第 2 に, ヒーッとかヒッと閔こえる鳴き声は, エゾムシク イが時々出す以外は, メボソムシクイやセンダイムシク イでは殆んど聞かれず, 一方, イイジマムシクイでは, 明らかに警戒していると思われる時以外にも, 非常に頻 繁に出し, これらの場合にもそらであった点。第 3 に, 近距離からの観察により, 外観上最も良く似ているセン
ダイムシクイに見られる白っぽい頭央線やそれに沿った 黒斑のないことを確かめたこと。第 4 亿，鳥のほらから 観察者に向かって近寄ってくることが何度かあったが， これに類した行動は, 伊豆諸島で繁殖するイイジマムシ クイで多く見られること，などである。

青野作業所一帯ではセンダイムシクイが繁殖し,イイ ジマムシクイが観察できた時期にも見られた。この場 合, 興味あることに, 前記した状況からもわかるよらに, イイジマムシクイはセンダイムシクイが生息している落 葉広葉樹林には見られず，照葉樹林や，落葉樹林でも照 葉樹林やスギ林に接した暗い部分にいることが多かっ た。

なお,ごく稀れではあるが, イイジマムシクイには伊 豆諸島内でも越冬する個体があり，近年記録された例と して, 次のものがある。

1. 八丈島名古付近, 1971 年 12 月 18 日, 茂田良光 氏 1 羽観察。

2. 三宅島あおさ山神社内, 1972 年 12 月 10 日, 佐 藤行雄氏 1 羽觀察。

3. 三宅島坪田部落美晴館付近, 1973 年 2 月 18 日, 佐藤行雄氏 2 羽観察。このうちの 1 羽は, カラーリング により，筆者と佐藤氏で 1972 年の繁殖期に同島伊豆部 落で個体識別したものであることがわかった。

報告して下さった佐藤・茂田両氏および前記の幸丸政 明氏に感謝する。

\section{引用文献}

樋口広芳, 1971: 島・鳥・進化, 日本鳥学会 10 月例会 での講演要旨.

石沢慈鳥, 1966: イイジマムシクイの渡り, 野鳥 238: 47.

日本鳥学会, 1958: 日本鳥類目録, 改訂四版 山階芳磨，1935: イヒジマメボソとウチヤマセンニフ. 鳥 40: 431 439.

(Received May 4, 1973)

\title{
Ecological Studies of Biomass of the Peafowl (Pavo cristatus)
}

\author{
Indra Kumar SHARMA
}

\section{孔雀の個体群に関する生態学的研究}

\footnotetext{
要 約: インドでは，孔雀は神聖な鳥として扱われ，国鳥となっているが，同時に個体数が多いので 農作物伩対する害鳥となっている。従って大農場のある村落では, 個体数も密度も最大である。しかし 大庭園では, 慨の関係から一般に考えられているほど個体数は多くない。
} 
一方餌の少ない谷間や不毛の村落, 天敵動物の多い地域では, その個体数は著しく少ない。

また人間が彼らの個体数の増減に大きな影響を及ぼしている。このほか植生, 天敵動物, 気象なども

個体群に重大な影響を及ぼしている。

性比は一般に雌のほうがすこし高いが，上述の不毛の地ではその逆の現象が見られる。

このように孔雀はインドでは人間生活と密接な関係を持っているが, その個体群の動態に関する研究

は殆どなかった。ここではその生態と個体群の動態に関して述べたい。

\section{Introduction}

The peafowl enjoys status of sacred bird and the national bird of India, because of that it enjoys protection by Indian masses, on account of that biomass of the peafowl is extraordinary high in several parts of India. As the peafowl is pest to agriculture, high population of it causes much nuisance to farmers so farmers hate this charming magnificient bird. Former ornithologists have not studied biomass of the peafowl. BLANFORD (1898) narrates forest, bushy ground near water and cultivated areas are favourite habitats of the peafowl. BAKER (1930) narrates the peafowl is found at every village and at streams of hills. FINN (1911) narrates it prefers to live near water. WHISTLER (1949) narrates low hills with stream, cultivated areas are its popular habitats. ALI (1968) narrates dence scrub jungle, deciduous jungle and foot of hill as favourite habitats of the peafowl. I studied ecological aspects of biomass of the peafowl at various typical habitats at and around Jodhpur in 1972.

\section{Method and Procedure}

Several typical habitats of the peafowl were selected for the study purpose around Jodhpur in the radius of $25 \mathrm{~km}$. Peafowl were counted rapidly in mass at food sites and roost sites which could give fairly accurate number of the peafowls at the habitat as almost all peafowls gather for food and roost otherwise they remain scattered. Here habitats I mean a particular area where peafowls of one place usually reside and move for food, rest and roost. In arid area at a small village the few peafowls reside there, there that is one habitat of the peafowl in a large region. At large town of fertile area peafowls of a village

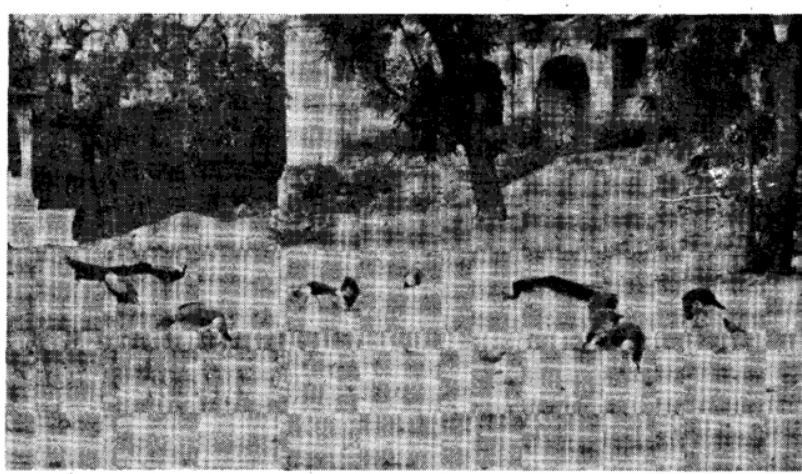

Fig. 1. Peafowls picking grains fed by the people of village. reside at different corners with rater variable enviroments with their own territories that constitute several habitats of the peafowl in a region.

\section{Physical Conditions of Jodhpur}

Jodhpur is situated at $26^{\circ} \mathrm{N}$ latitude and $73^{\circ} \mathrm{E}$ longitude at altitude of 242 meters M.S.L. It is a semiarid region having some quite arid areas as well as green oasis of agriculture farms and large gardens. Annual rainfall is $365 \mathrm{~mm}$, the rains are mainly in JulyAugust $240 \mathrm{~mm}$ monsoons. Maximum temperature occurs in June $45^{\circ} \mathrm{C}$ and minimum in January $4^{\circ} \mathrm{C}$.

\section{Habitats and Populations of the Peafowl}

\section{Ratanada}

It is suburb of Jodhpur having some large residental gardens and some religious people feed them together with pigeons and other birds. There are four peacocks and four peahens. Peafowls emigrated here from Raikabagh Palace garden and Umed Bhavan Palace garden due to population pressure at the native habitat. Total population comes to eight at the habitat in the area of $1.5 \mathrm{~km}^{2}$ that makes population density 5.5 (whole figure five) peafowls per square kilometers. Sex ratio comes to $1: 1$ male to female (cock to hen).

\section{Rail House Colony}

At suburb of Jodhpur there is large garden at the residence of Divisional Superintendent of Railways besides that there are several other fair size large residental gardens in the adjoining area of bungalows of other officers. Few religious people also feed grains to local peafowls near the road passing through the bungalows. There are four peacocks and five peahens in the habitat of area $0.8 \mathrm{~km}^{2}$ that makes the density 11.2 and sex ratio $1: 1.2$ male to female.

Umed Bhavan Palace

It is a large palace of the former ruler with large garden at small hill with scrub jungle, situated about two kilometers from the city area. Local people and staff personnels feed food grains to the peafowl. There are eleven peacocks and fourteen peahens in the area of about $0.7 \mathrm{~km}^{2}$ making population density 17.5 peafowls per square kilometers and sex ratio comes to $1: 1.22$ male to female. Mahamandir Farm

It is a medium size agriculture farm at out 
skirt of urban area. Local people feed enough quantity of food grains to the peafowl. There are 18 peacocks and 23 peahens at the habitat in the area of about $1.2 \mathrm{~km}^{2}$ making density 34.1 peafowls per $\mathrm{km}^{2}$. Sex ratio is $1: 1.27$ male to female.

Mandore Gardens

It is a large public garden $10 \mathrm{~km}$ away from urban area. Here there is large enough area of lawn and shrubbery, some supplementary food is acquired from adjoining human locality and at valley areas. Here there are 8 peacocks and 8 peahens in the area of $3 \mathrm{~km}^{2}$. making the population density 5.3 peafowls per square kilometers and sex ratio of $1: 1$ male to female.

Surpura Village

It is an agriculture farm area $15 \mathrm{~km}$ from the city. Here cultivation is done throughout the year and villagers feed food grains to peafowl and other birds at the squares of the village. Here there are 53 peacocks and 72 peahens in the area of about 3.5 $\mathrm{km}^{2}$ making the population density 35.7 peafowls per square kilometers and sex ratio $1: 1.33$ male to female. Nandadi Village

It is a small village where some cultivation is done during rainy season. Peafowls acquire food from cultivated land and partially from jungle area and the local people also feed them. Here there are 3 peacocks and three peahens. These live in large area of 5 $\mathrm{km}^{2}$, that makes 1.2 peafowls per square kilometer density and sex ratio $1: 1$ male to female.

Beriganga Valley

It is light forest valley $15 \mathrm{~km}$ from Jodhpur with a perennial stream. Peafowls acquire food in the jungle of valley and plain near by. There are three peacocks and two peahens in the area of $3 \mathrm{~km}^{2}$, that makes population density of 1.6 peafowls per square kilometers, the sex ratio comes to $3: 2$ male to female.

Table 1. Various aspects of population of the peafowl at some typical habitat Jodhpur in April 1972

\begin{tabular}{l|r|r|r}
\hline \multicolumn{1}{c|}{ Habitat } & Biotope & Dencity & Sex ratio \\
\hline Ratanada & 8 & 5.3 & $1: 1.00$ \\
Rail House & 9 & 11.2 & $1: 1.25$ \\
Umed Bhavan & 25 & 17.5 & $1: 1.22$ \\
Mahamandir & 41 & 34.1 & $1: 1.27$ \\
Mandore & 16 & 5.3 & $1: 1.00$ \\
Surpure & 135 & 35.7 & $1: 1.33$ \\
Nandadi & 6 & 1.2 & $1: 1.10$ \\
Beriganga & 5 & 1.6 & $1.5: 1.00$ \\
\hline
\end{tabular}

Study of biotope, population density and sex ratio at various habitats (Table 1 ) reveals that biotope is highest at Surpura village where there are large evergreen agriculture farms and the local people feed supplementary food of food grains. Biotope is also enough high at the agriculture farm of Mahamandir where local people feed grains. Population is fairly high at large garden (Umed Bhavan) where local people feed food grains to the peafowl. Population of the peafowl is not high at large garden of Mandore where supplementary food of grains is not available to the peafowl. Biotopes are poor at arid village i.e. Nandadi and valley i.e. Beriganga having scarcity of food throughout the year. This shows evergreen agriculture farms where the local people feed the peafowls makes largest biotope of the peafowl.

Population density also shows somewhat similar trend of biotope, highest at village having large agriculture farms and food grains fed by the local people and it is lowest at small arid village having cultivation only once a year having scarcity of food most of the year. Population density is comparatively higher at gardens where local people feed some food grains there the peafowl has not to wonder large area in search of food and shelter otherwise large home range makes the population density lower.

The tables also reveals that sex ratio of male is slightly poor than female in general, female ratio increases with fertility (food availability) of the habitat, at some what hardy habitat female ratio turns poor, according to my observations it is because female (peahen) is delicate by nature, she cannot withstand hard life to wonder long distances in search of food and adverse climate of the habitat. Peahens suffer much at valley where enough number of carnivora animals hunt incubating peahens. Secondly male chick is hardly in nature so he can withstant hard life of the habitat where as female chick comparatively perishes in adverse conditions of arid habitat.

Vegetation and Population Density

Vegetation provide food and shelter to the peafowl. Grasses and cereal crops provide abundance of food of seeds (or grains) and leaves blades, shrubs also provide some food to the peafowl of their seeds and sprouts. Because of enough food supply at grassland or crop fields, population of the peafowl is found high at agriculture farms. Trees are required only for rest and roost purpose, requirement of them is few in number hence habitat having large number of trees but less abundance of grasses there, population of the peafowl is found less as it was found less in Mandore gardens and Beriganga valley. Agriculture farms make a ideal habitat for the peafowl having abundance of grasses (or cereal crops) for food and the few trees growing in farms serves for rest and roost because of that population of the peafowl is found highest at agriculture farms. 
It was observed that from less green habitat significant number of peafowls particularly peahens migrate to close by more green habiat a farm or garden for adequate food and shelter in the draught weather that is from April to June and they return back on commence of rainy season i.e. July when grasses again grow and trees sprouts making the native habiat amiable enough to live.

Man and Population of the Peafowl

It was observed that man has effected the population of the peafowl both positive as well as negative.

Positive Role by Man

Local people of Jodhpur have played extraordinary positive role in increasing population of the peafowl at several places in several ways. Here local people consider the peafowl as a sacred bird hence they feed food grains and in this way they solve its major problem of food in the semiarid and arid region. Because of plenty of food natality rate increases and mortality rate decreases as man provides protection to nest of the peahen from carnivora that greatly increases the population of the peafowl. Because of that reason population of the peafowl is very high at villages like Surpura.

Local people never hunt or kill the peafowl, neither they permit others to do so, hence mortality rate of the peafowl is very low and that is only by natural death or rarely by some carnivora. There are several places in India where the peafowl was not considered sacred bird but it was treated as game bird at such places it got vanished or became rare. Here at some military colonies where outsider non-religious personnels who do not consider the peafowl as sacred bird population of the peafowl has got very low by illegal stealth poaching by them. Some notorious boys and wicked persons occassionally rob nests of the peafowl and harm to population growth of the peafowl.

\section{Carnivora Animals and Population of the Peafowl}

The dog is the most serious enemy of the peafowl as it robs large number of nests and brood of the peafowl hence population growth becomes very poor at habitats infested with stray dogs. Mahamandir farm is infested with stray dogs hence population of the peafowl not reached to climax otherwise it is very suitable habitat. Dog, wolf, cat and panther etc. are natural enemies of the peafowl but they seldom succeed to kill the adult peafowl but fairly harm population growth in jungle as the dog does in urban and semi-urban habitats by robbing nests and broods of the peafowl at valleys i.e. Beriganga.

Effect of Climate on Population

It was observed that weather directly or indirectly effects population of the peafowl. At arid region weather is mostly extreme so suitable (amiable) period for breeding is very short one, hence there breeding occurs less than that habitats of fertile areas having amiable weather for longer period as large percentage of peahens population gets chance to breed and when nest has been robbed she may breed second time in prolong breeding season.

It was observed that irregular and less rains in JulyAugust (breeding season) highly decrease breeding of the peafowl which reduces population growth. Rains also effect grasses and crops thus effect food availability at the habitat throughout the year. In this way rains indirectly effects population growth of the peafowl.

As already discussed that in summer in semi-arid regions delicate natured peafowls particularly peahens migrate from drier habitat to close by greener habitat for adequate food and shelter against scorching heat as dry habitat there is scarcity of food (vegetables and seeds) and dense shade trees and shrubs for midday cool resort. It was observed that about 20 to $50 \%$ of the population of dry habitats migrate to close by greener habitat depending upon conditions of the native habitat and vicinity of amiable greener habitat and its capacity to accomodate number peafowls without strain of over population. In this way population of habitat in a semi-arid region fluctuates with weather, it decreases in summer at an arid habitat and increases at fertile green habitat and become normal again in rainy season.

\section{Sex Ratio and Population Growth of the Pesfowl at the Habitat}

It is obvious from the table that sex ratio of the peafowl is slightly higher than peacock at average habitat hence breeding potentionality is high as actual reproductive partner is large enough in number. As the peacock does not take part in parental care one peacock can fertilize large number of peahens. It is to be noted that only 50 to $60 \%$ peahens at the habitat breed other do not because of under or over age or other adverse factors retarding breeding activities. Many ornithologists as Blanford, Whistler and Baker etc. have narrated that peacock keeps harem of several peahens, according to my observations it is not true. Sex ratio (Table 1) of habitat reveals that there cannot be harem of several peahens with a peacock as ratio of hens is only slightly above cock second no group sex segregation is observed in the peafowl as found in some primates and ungulates. Sex ratio of peahen is found lower at arid habitat that is ecological advantageous as because of low number of hens there would be lower breeding and hence there would be lower breeding and hence there would be less starvation of brood and population at an arid habitat.

\section{Natality Success and Population of the Peafowl}

It was observed that breeding is higher at fertile 
habitats but natality success depends upon survival of nests and brood, that was found good where there are less number of carnivora animals particularly stray dogs. Habitats infested with stray dogs shower poor natality success $(16 \%)$ means the breeding is high but popplation dynamics is low hence population cannot reach to the climax. At Surpura village population of the peafowl is high because breeding success (natality success) is high (53\%), at Mahamandir population is not high as it should be, as natality success is poor because of habitat infested with stray dogs. At Beriganga valley also population is poor because of natality success is poor because of robbing of large number of nests by predator animals as foxes, jackals and wolves.

\section{Mortality and Population of the Peafowl at Habitats}

Here peafowl is protected bird so its mortality by man is nil hence population does not decrease because of hunting as it happens to game birds. Formerly at some regions the peafowl was not protected and was considered as game bird, there its population decreases to rare or vanished altogether. As the local people feed the peafowl it does not suffer death due to starvation. There is no serious predator animal to the adult peafowl so such mortality is also extremely low hence population of the peafowl is found far high even at semi-arid habitats. At habitats of jungles having large number of predator animals less quantity of food and poaching by some savage tribes mortality of the peafowl is high enough hence population of the peafowl is found meagre at such habitats.

\section{Dispersal of Population}

It was observed that when a habitat becomes over populated in respect to availability of food and rest and roost space some versatile peacocks and few peahens move to some distant places in search of food and shelter if they find suitable place with this point of view of adequate food and shelter within the radius of three kilometers, they gradually settle there and make such place as there new habiat. These settle there and make such place as new habiat. There their population may increase in successive years if favourable conditions as adequate food shelter and safety at the habitat prevails. At much hardy place only one or two peacocks emigrate there, there the population remain stationary for years until some one dies or killed or peahen or peahens emigrate there and breeding begins to occur. Such emigration was observed from Umed Bhavan Palace to Ratanada which has been discussed earlier.

It was observed that if carnivora animal frequently visits at the habiat or some people often try to molest the peafowl, peafowls migrate to near by safe place, they may return back in the few days if threat to their life ceases at the native habitat they may return back in the few days otherwise the altered safe place becomes the permanent habitat.

\section{Acknowledgements}

I acknowledge my gratfulness to local farmers who provided me all possible facilities in their farms for my observations. I am also grateful to Prof. S.D. Mishra, Dean of Science Faculty, University of Jodhpur and Dr. Ishwar Prakash, Animal Ecologist, Centeral Arid Zone Research Institute Jodhpur for their guidance and advice in my work.

\section{Reference}

ALI, Salim, 1961: The Book of Indian Birds BLANFORD, W., 1898: Fauna of British India (Vol. IV)

Dharamkumarsing hji, 1956: Birds of Saurastra (India)

FINN, Frank, 1911: Game Birds of India and Asia

Messurier, A. 1904: Game, Shore and Water Birds of India

SHARMA, Indra Kumar, 1965: Some observation of the peafowl at Jodhpur 'Peacock' 2(3): 26 27

, 1969: Habitat et compaortment du Pavon 'Alauda' 57(3): 219 223

$28 \sim 33$

1970: Analyse ecologique des parades Pavon, 'Alauda' 38(4): 290 294

1972: Ecological study of rest and roost behaviour of the Peafowl, 'News Letter for Bird Watchers' 12(6): 5 8 and 12(7): 5 8

1972: Etude Ecologique ce production de

Pavon, 'Alauda' XL(4): 378 384

(Received May 4, 1973) 